7. Reprod. Fert. (1969) 19, 185-186

\title{
HISTOCHEMICAL DEMONSTRATION OF DRUG INTERFERENCE WITH PROGESTERONE SYNTHESIS
}

\author{
LARS-ERIK APPELGREN \\ Department of Pharmacology, Royal Veterinary College, Stockholm, Sweden
}

(Received 4th November 1968)

Autoradiography of some labelled steroid hormone precursors in mice has shown that these substances are localized to a great extent in sites of steroid hormone formation (Appelgren, 1967). Pregnenolone-the immediate precursor of progesterone-was specifically accumulated in the corpora lutea (Pl. 1, Fig. 1).

Some synthetic substances of diphenyl alkene character, F6060, bis- $(p$ hydroxyphenyl)cyclohexylidenemethane, (Ferrosan Ltd, Sweden), and its derivatives, F6066, F6103, have also been shown to concentrate in corpora lutea (Hanngren, Einer-Jensen \& Uliberg, 1965a; Appelgren, Einer-Jensen \& Ullberg, unpublished observations). It was postulated that these substances might interfere with the corpus luteum function, and perhaps with progesterone synthesis. When tested pharmacologically they were found to have antigestagenic properties (Hanngren, Einer-Jensen \& Ullbert, 1965b; Einer-Jensen, 1968). It was later shown in vitro that $\mathrm{F} 6066$ reduced the synthesis of progesterone from pregnenolone by interference with $\Delta^{5}-3 \beta$-hydroxysteroid dehydrogenase and/or isomerase when ovaries or adrenals were incubated (Larsson \& Stensson, 1967).

A modified histochemical method for studying the enzyme that converts pregnenolone to progesterone ( $\Delta^{5}-3 \beta$-hydroxysteroid dehydrogenase) on whole body sections from mice (Appelgren, 1967) seemed to be well suited for testing the enzyme blocking activity of such substances and similar compounds. The original method by Wattenberg (1958) was applied to whole body sections on tape, which were cut according to the method of Ullberg (1954). The sections were incubated at $+38^{\circ} \mathrm{C}$ in a buffered medium containing the specific substrate (pregnenolone) dissolved in dimethylformamide, coenzyme (NAD) and a tetrazolium salt (NitroBT). If the substrate specific dehydrogenase is present in the tissue, the tetrazolium salt will be changed to blue formazan crystals, which precipitate at the site of reaction. Diaphorase is necessary for the reaction and Pl. 1, Fig. 2 shows that this enzyme is present in practically all organs in the body.

The advantage of using whole body sections is that the relative concentration of different tissues treated in exactly the same way can be compared in the same section.

Substances which are likely to interfere with progesterone synthesis by enzyme blocking activity in different organs or cell systems can thus be tested in vitro by adding them to the incubation medium. The method can also be used for in vivo studies if the substances to be tested are injected into the animals before 
freezing and sectioning. The enzyme activity in these animals can then be compared with that in control animals. The substances tested by this whole body method were F6060, F6066 (bis-( $p$-acetoxyphenyl)cyclohexylidenemethane), F6103 (bis-( $p$-acetoxyphenyl)-2-methyl-cyclohexylidenemethane), and F6204 (bis-( $p$-hydroxyphenyl)-2-methyl-cyclohexylidenemethane).

Plate 1, Fig. 3 is an example of $\Delta^{5}-3 \beta$-hydroxysteroid dehydrogenase activity in a whole body section with pregnenolone as a substrate. If a similar section was incubated together with $\mathrm{F} 6103(1.5 \mu \mathrm{g} / \mathrm{ml})$ the strongest inhibition of enzyme activity was seen in the ovary (Pl. 2, Fig. 4). This inhibition could also be studied in vivo in animals which received the substances $20 \mathrm{hr}$ before slaughter (Pl. 2, Fig. 5). Plate 2, Fig. 6 shows that the $\Delta^{5}-3 \beta$-hydroxysteroid dehydrogenase activity is still present in the interstitial parts of the ovary, while the corpora lutea show very weak activity, when the animal was injected $20 \mathrm{hr}$ earlier with $1 \mathrm{mg}$ F6204. This difference in enzyme blocking action is perhaps because F6204 is not taken up by the interstitial tissue.

\section{REFERENCES}

APPELGREN, L.-E. (1967) Sites of steroid hormone formation. Autoradiographic studies using labelled precursors. Acta physiol. scand. Suppl. 301, 1.

EINER-Jensen, N. (1968) Antifertility properties of two diphenylethenes. Acta pharmac. tox. 26, Suppl. 1,1 .

Hanngren, $\AA$., Einer-Jensen, N. \& Ullberg, S. (1965a) Distribution pattern of a non-steroid compound with endocrine actions, ${ }^{14} \mathrm{C}$-bis $(p$-hydroxyphenyl)cyclohexylidenemethane (compound F6060) and its diacetate (compound F6066). Acta endocr., Copenh. 50, 35.

Hanngren, A., Einer-Jensen, N. \& Ullberg, S. (1965b) Specific uptake in corpora lutea of a nonsteroid substance with anti-gestagenic properties. Nature, Lond. 208, 461.

LARsson, H. \& Stensson, M. (1967) Effect of bis ( $p$-hydroxyphenyl)-cyclohexylidenemethane (F6060) on the conversion of pregnenolone to $\Delta^{4}-3$-ketosteroids in vitro. Acta endocr., Copenh. 55, 673.

Ullberg, S. (1954) Studies on the distribution and fate of $S^{35}$-labelled benzylpenicillin in the body. Acta radiol. Suppl. 118.

WattenBerg, L. W. (1958) Microscopic histochemical demonstration of steroid-3 $\beta$-ol-dehydrogenase in tissue section. F. Histochem. Cytochem. 6, 225.

\section{EXPLANATION OF PLATES \\ PLATE 1}

Fig. 1. Detail of whole body autoradiogram (b) showing the distribution of $4-{ }^{14} \mathrm{C}-$ pregnenolone in a pregnant mouse. Selective accumulation in corpora lutea and yolk sac placenta. (a) is the corresponding section stained with haematoxylin-eosin.

FIc. 2. Whole body section of a female mouse showing the distribution of diaphorase after incubation with reduced NAD. The reaction is seen in almost every tissue in the body. Fig. 3. Whole body section from a pregnant mouse showing the $\Delta^{5}-3 \beta$-hydroxysteroid dehydrogenase activity with pregnenolone as a substrate. Note the high enzyme activity in the ovary.

\section{PLATE 2}

FIG. 4. Details of ovaries in whole body sections from a pregnant mouse showing the $\Delta^{5}$-3 $\beta$-hydroxysteroid dehydrogenase activity using pregnenolone as a substrate. (a) shows the inhibitory effect on enzyme activity of $\mathrm{F} 6103$, added to the incubation medium. (b) is the corresponding control section.

Fig. 5. Whole body section from a pregnant mouse which received $1 \mathrm{mg} \mathrm{F} 610320 \mathrm{hr}$ before slaughter (a). The section was incubated with pregnenolone to show the $\Delta^{5}-3 \beta$ hydroxysteroid dehydrogenase activity. Note the weak enzyme activity in the ovary. (b) is a corresponding section from a control animal. Note the strong reaction in the ovary. $\times 10$.

Fic. 6. Details of ovaries from pregnant mice showing the $\Delta^{5}-3 \beta$-hydroxysteroid dehydrogenase activity after incubation with pregnenolone. (a) is from an animal that received 1 mg F6204 $20 \mathrm{hr}$ before slaughter. (b) is from a corresponding control animal. Note that the enzyme activity in the corpus luteum is inhibited while the activity in the interstitial tissue seems to be intact. $\times 48$. 


\section{PLATE 1}
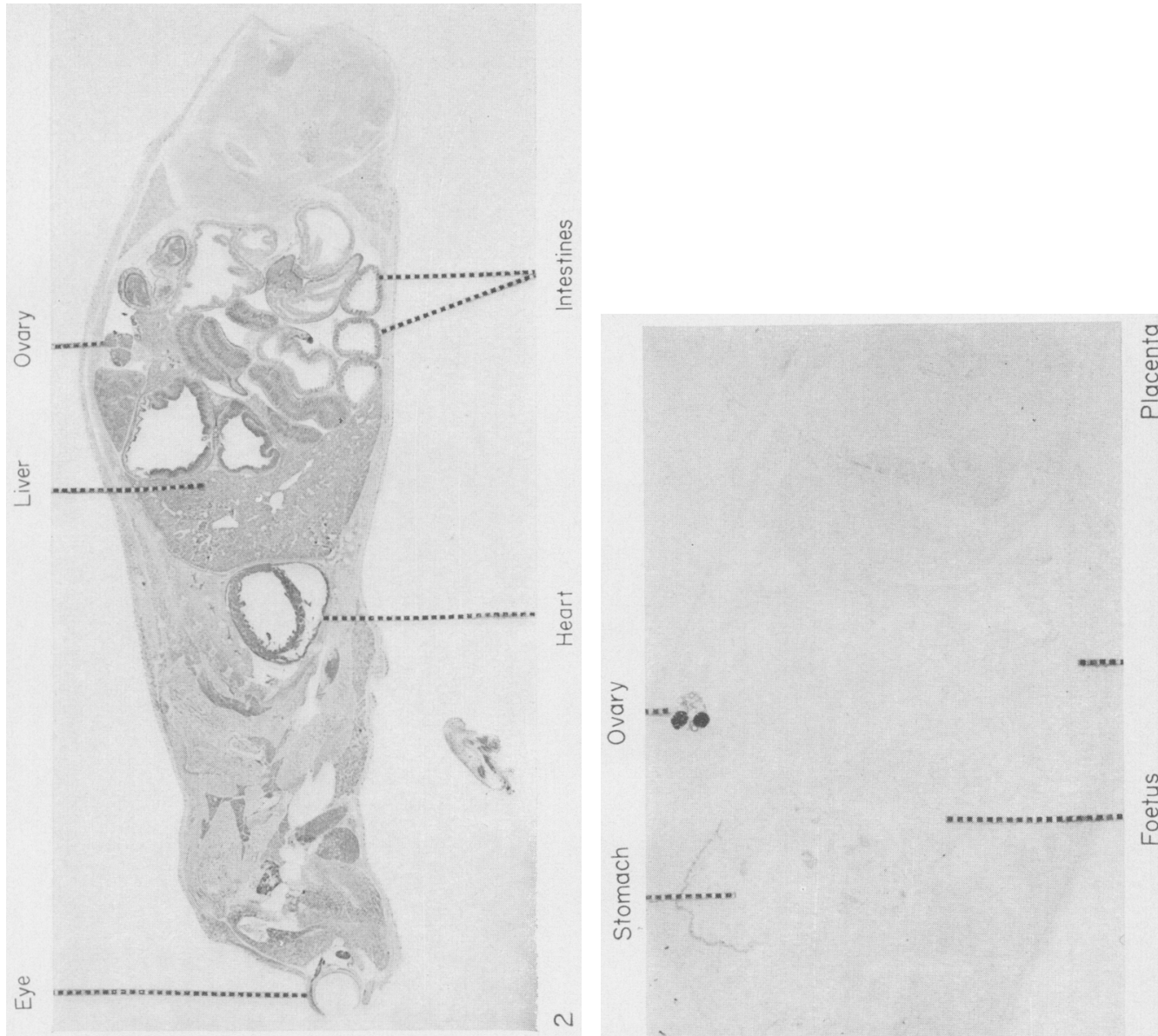

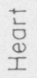
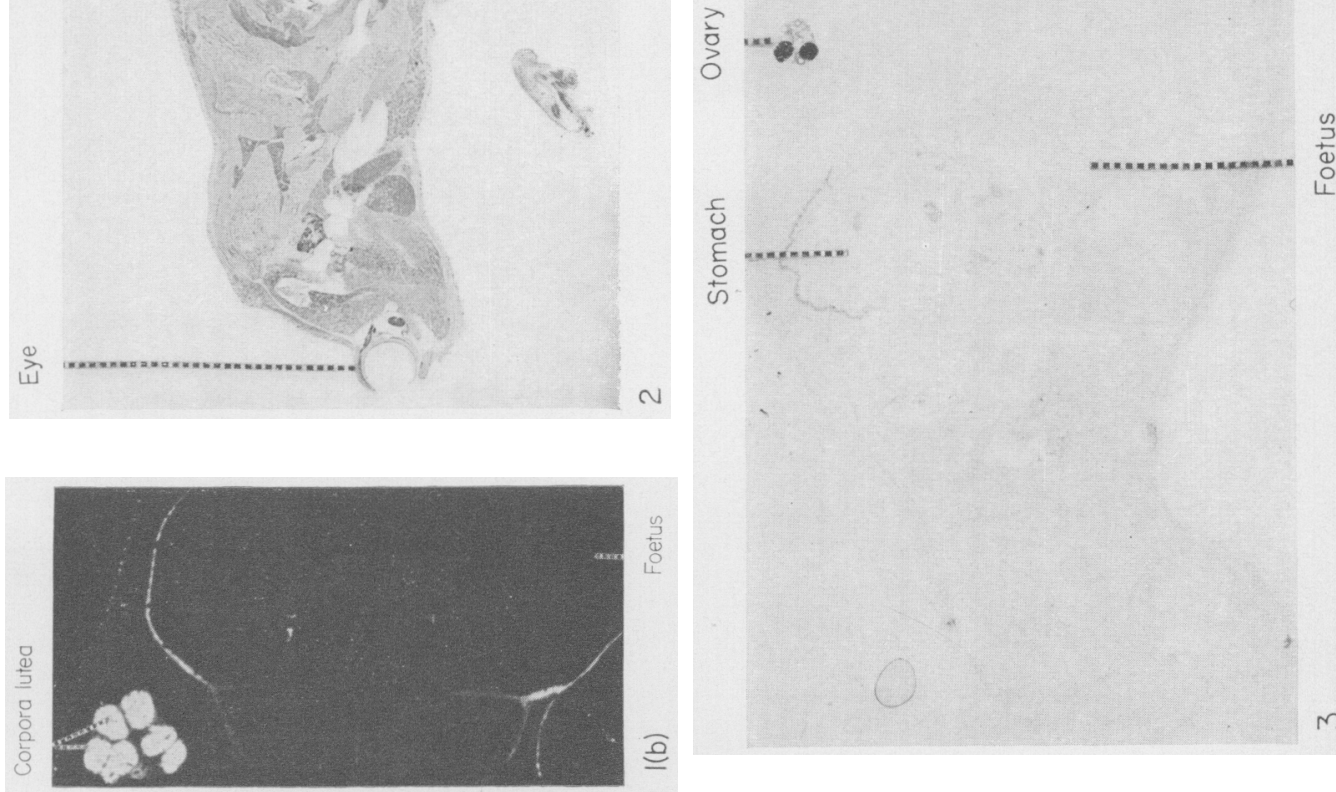

골
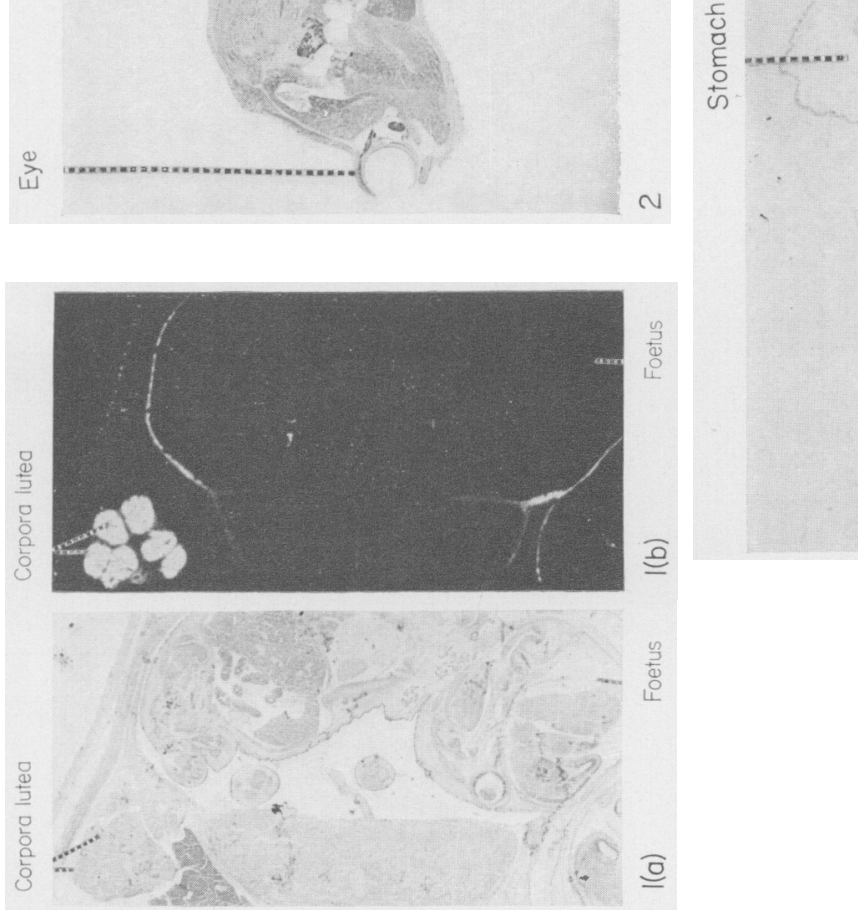

(Facing p. 186) 
PLATE 2
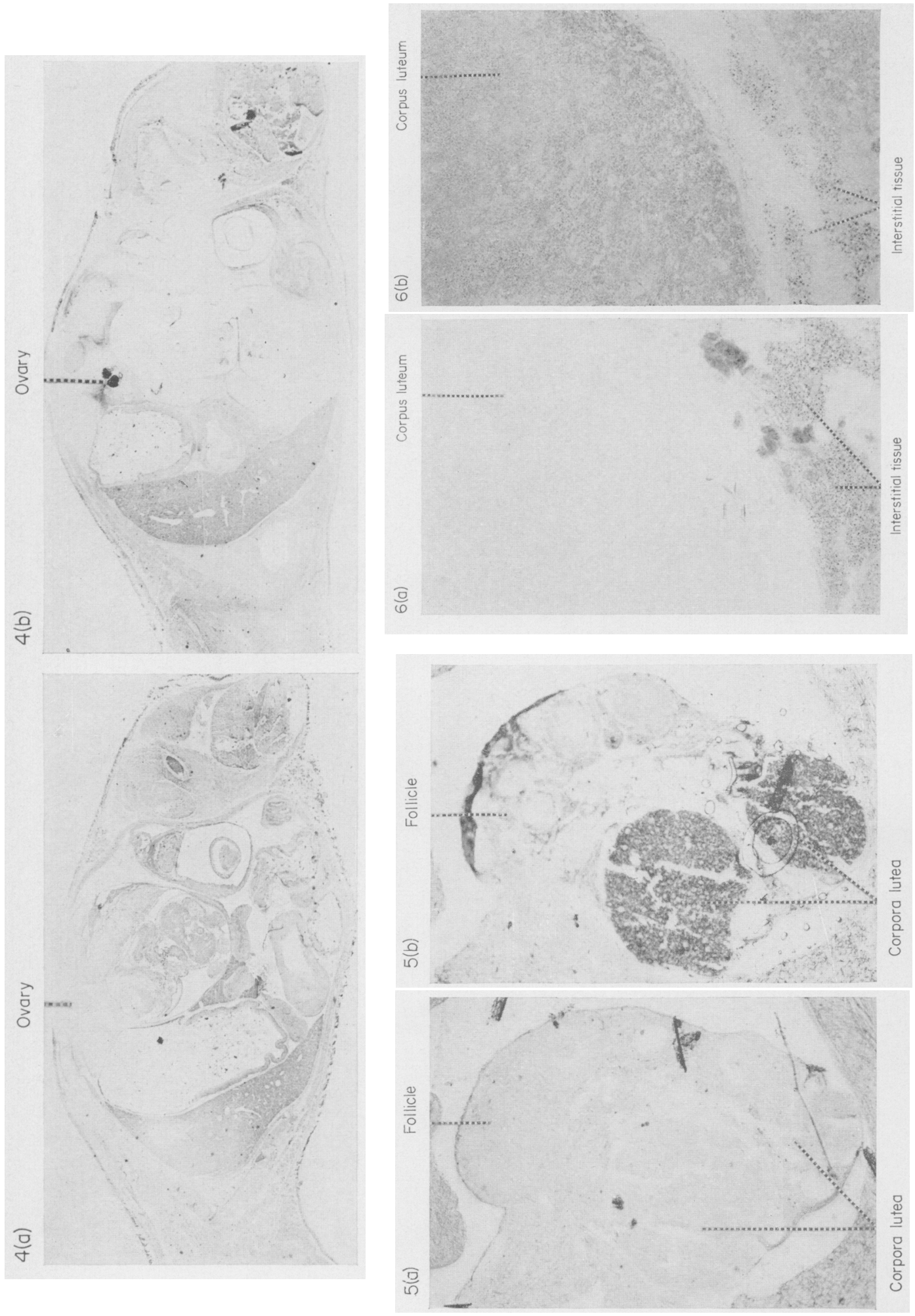

Downloaded from Bioscientifica.com at 04/26/2023 10:29:41AM via free access 